\title{
The Optimum Position of Impeller Splitter Blades of a Centrifugal Pump Equipped with Vaned Diffuser
}

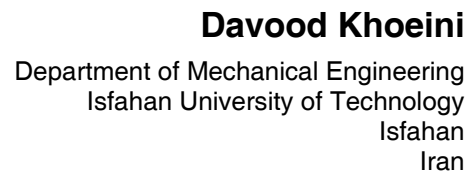

Mohammad Reza Tavakoli

Department of Mechanical Engineering Isfahan University of Technology Isfahan

The present investigation has been concentrated on the optimum, circumferential position of the impeller splitter blades of a centrifugal pump equipped with vaned diffuser, numerically and experimentally. In fact, five different circumferential positions of the impeller splitter blades of central and shifted by $+\mathrm{Pi} / 10,+2 \mathrm{Pi} / 10,-2 \mathrm{Pi} / 10,-\mathrm{Pi} / 10(+$ is the rotating direction and $P i$ is the distance between the two main blades) have been analyzed. Experimental and numerical results reveal good agreement and maximum head deviation of 4.8 percent. Data analyses indicated that overall efficiency of the pump increased by 1.7 percent at BEP, Best Efficient Point, by using the impeller with shifted splitter blades by $+2 \mathrm{Pi} / 10$ in comparison with the impeller with central splitter blades. Moreover, it is found that the impeller with central splitter blades has the highest head values at all flow rates as it is 7.5 percent higher than shifted splitter blades by $-2 \mathrm{Pi} / 10$.

Keywords: Centrifugal pump, impeller splitter blades, optimum position, performance curve, numerical and experimental study.

\section{INTRODUCTION}

Splitter blades are employed in centrifugal pump impellers since they can provide higher impeller performance rather than that of the impellers without impeller splitter blades.

The reason is that splitter blades have no blockage effect in the impeller inlet and impeller inlet area by adding splitter blades remains constant. In addition, proper splitter blades can provide more uniform flow field on the impeller passages as well. Therefor approaching to the optimum characteristics of impeller splitter blades has been regarded as an inseparable part of centrifugal pump research along with the other effec-tive methods to improve the performance of pumps [1-5].

Ye et al. [6] investigated the impacts of splitter blades of a centrifugal pump. They observed that deviated splitter blades by $5^{\circ}$ to the suction side of the long blade have the highest performance and lowest pressure fluctuation. In fact, they observed that head was enhanced by 12 percent in this case. Design methods of a low specific speed centrifugal pump with splitter blades were analysed by Yuan et al. [7].

It is obtained that there is more uniform velocity distribution inside the splittered impeller and the jetwake flow at peripheral area of splittered impeller is also modified. Kergourlay et al. [8] surveyed a centrifugal pump equipped with impeller splitter blades. Higher head and lower pressure fluctuation were accomplished by splittered impeller rather than the impeller

Received: October 2017, Accepted: December 2017

Correspondence to: Davood Khoeini,

Isfahan University of Technology, Department of

Mechanical Engineering, Isfahan, Iran

E-mail: d.khoeeni@me.iut.ac.ir

doi:10.5937/fmet1802205K

(C) Faculty of Mechanical Engineering, Belgrade. All rights reserved without impeller splitter blades. The effects of splitter blades on a deep well pump performance were calculated by Golcu et al. [9]. Their results showed an energy saving of 6.6 percent owing to the beneficial effects of splitter blades. Miyamoto et al. [10] carried out an analysis on the splitter blades of a centrifugal pump.

Higher tangential velocity and total pressure and lower blade loading were obtained by using splittered impeller compared to the impeller without impeller splitter blades. Flow characteristics of a centrifugal pump with splittered impeller were presented by LD and JL [11]. Their results indicated that higher performance is achieved by negligible shift of splitter blades toward the rotating direction.

As described above, it is seen that neither the impacts of circumferential positions of impeller splitter blades equipped with vaned diffuser nor the optimum place of impeller splitter blades in this condition have not been regarded to the knowledge of the authors, yet. Therefore, numerical and experimental investigation have been conducted to study the optimum circumferential position of impeller splitter blades of $\mathrm{L}=0.5 \mathrm{Ls}$ (Ls is the length of the main blade) in five different cases of the central (splitter blades located in the centre line of the two main blades) and displaced by $+\mathrm{Pi} / 10$, $+2 \mathrm{Pi} / 10,-2 \mathrm{Pi} / 10,-\mathrm{Pi} / 10(+$ is the rotating direction and $\mathrm{Pi}$ is the distance between the two main blades).

\section{CENTRIFUGAL PUMP PARTS}

As shown in Fig. 1, the centrifugal pump contains different parts of inlet region, impeller region and volute casing region.

Diameters of suction pipe, discharge pipe, diffuser and impeller and also numbers of diffuser vanes and impeller blades as well as leading and trailing angles of blades, thickness and height of blades are mentioned in Table 1. 


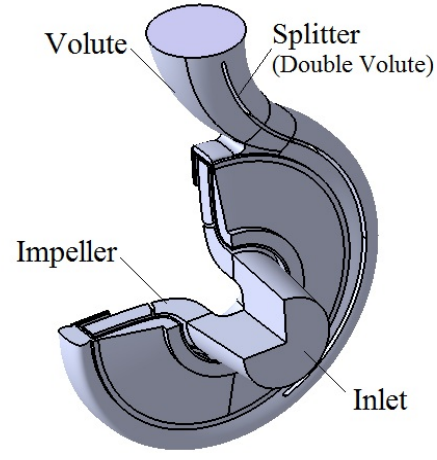

Fig. 1 Centrifugal pump parts

Table 1 Centrifugal pump specifications.

\begin{tabular}{|l|l|l|}
\hline Impeller & Impeller diameter & $500 \mathrm{~mm}$ \\
\cline { 2 - 3 } & Inlet blade angle & $19^{\circ}$ \\
\cline { 2 - 3 } & Outlet blade angle & $27^{\circ}$ \\
\cline { 2 - 3 } & Number of blades & 4 \\
\cline { 2 - 3 } & Blade height & $38 \mathrm{~mm}$ \\
\cline { 2 - 3 } & Blade thickness & $8 \mathrm{~mm}$ \\
\hline Diffuser & Diffuser inner diameter & $504 \mathrm{~mm}$ \\
\cline { 2 - 3 } & Diffuser outer diameter & $604 \mathrm{~mm}$ \\
\cline { 2 - 3 } & Number of vanes & 6 \\
\cline { 2 - 3 } & Base circular width & $42 \mathrm{~mm}$ \\
\hline Volute & Suction pipe diameter & $200 \mathrm{~mm}$ \\
\cline { 2 - 3 } & Discharge pipe diameter & $200 \mathrm{~mm}$ \\
\hline
\end{tabular}

\section{EXPERIMENTAL SETUP}

All experimental test facilities are demonstrated in Fig. 2. By using water at $25^{\circ} \mathrm{C}$ in the reservoir tank $\left(12 \mathrm{~m}^{3}\right)$ all experiments have been conducted based on [12] and [13] and eventually, performance curves of the centrifugal pump have been obtained thoroughly. Indeed, the tested pump, Over Hung type, was driven by an electric motor, $1475 \mathrm{rpm}$, and the operation of pump in different flow rates have been controlled with a globe valve (200 $\mathrm{mm}$ ) at the discharge pipe. In order to measure the flow rate (Q) an electromagnetic flowmeter (DN200) was used with a precision of $\pm 0.5 \%$. Besides, two pressure gages (bourdon tube) with a precision of $\pm 0.1 \%$ were used to measure the pressure values at the inlet and outlet pipe. Sectional view of the impeller with vaned diffuser and all splittered impellers in the present study are depicted in Fig. 3.

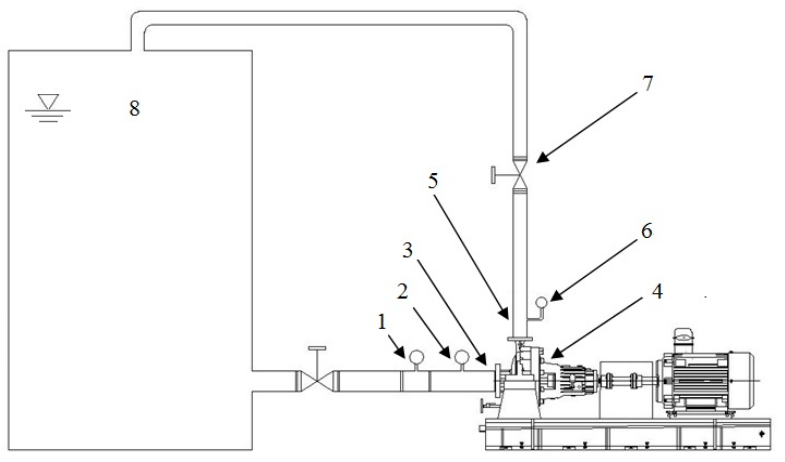

\begin{tabular}{|l|l|}
\hline 1. Flow meter & 5. Discharge pipe \\
\hline 2. Pressure gage & 6. Pressure gage \\
\hline 3. Suction pipe & 7. Globe valve \\
\hline 4. Tested centrifugal pump & 8. Water storage \\
\hline
\end{tabular}

Fig. 2 Experimental setup
Actually, all relative ratios of various parameters to the length of the splitter blades and main blades are same such as leading angle of blades, trailing angle of blades, blade height and so forth. But merely their lengths are different. Before performing experiments each configuration, impeller with central splitter blades and shifted splitter blades by $+\mathrm{Pi} / 10,+2 \mathrm{Pi} / 10,-2 \mathrm{Pi} / 10$ and $-\mathrm{Pi} / 10$, have been investigated numerically and then experiments have been carried out.

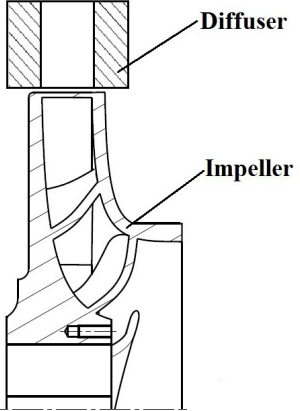

(a)

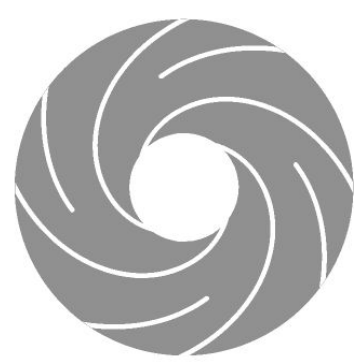

(c)

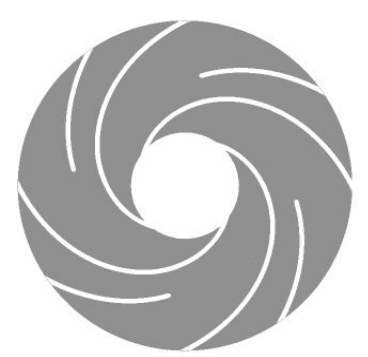

(e)

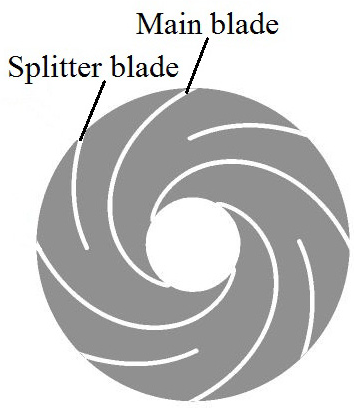

(b)

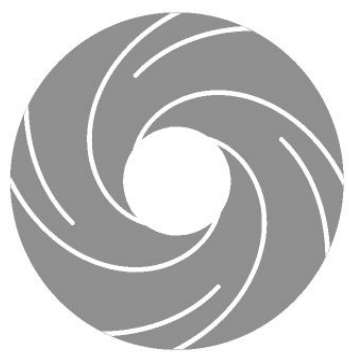

(d)

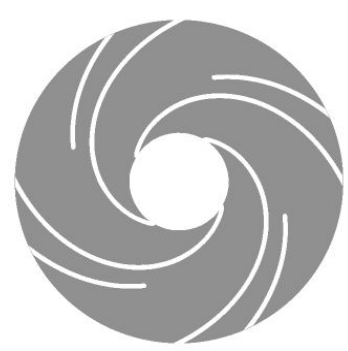

(f)
Fig. 3 (a) Sectional view of the impeller and vaned diffuser for centrifugal pump. (b) Central splitter blades (c) Shifted splitter blades by $+\mathrm{Pi} / 10$ (d) Shifted splitter blades by $+\mathrm{Pi} / 10$ (e) Shifted splitter blades by -Pi/10 (f) Shifted splitter blades by $-2 \mathrm{Pi} / 10$.

\section{NUMERICAL ANALYSES}

The incompressible Navier-Stokes equations in this study have the following forms [14]:

$$
\begin{aligned}
& \nabla \boldsymbol{U}=0 \\
& \rho \nabla \cdot(\boldsymbol{U} \boldsymbol{U})=-\nabla p+\nabla \cdot(\tau)+\rho \boldsymbol{g}+\boldsymbol{F}
\end{aligned}
$$

where $\rho$ and $U$ are fluid density and velocity respectively and $p, \tau$ and $F$ present pressure, stress tensor and source term in computations. Central difference was used for discretization scheme for diffusion terms. High resolution discretization scheme was used for convective terms. Pressure boundary condition, based on experimental test conditions, is specified at inlet section 
and mass flow rate condition is utilized at the outlet boundary in this steady state study. No slip wall condition is specified for all walls of computational domain boundaries, including of impeller, casing volute and inlet wall regions. Besides, in all computations SST turbulence model has been utilized as well.

\section{MESH GENERATION AND VERIFICATION}

Figure 4 indicates computational domain. As shown, grids have been refined in the acute regions and structured grid has been specified in the near wall regions and unstructured grid has been employed in other regions. For reducing the computation time and increasing the accuracy, the torque value has been regarded as the parameter of evaluation for the effect of grid size on the calculations. Finally, by different iterations the optimum element number was obtained and used $(1891 \times 1000$ cells), see Table 2. Pressure contours in all cases of grid study are depicted in Fig. 5 (a to d). Actually, by refining grids, the pressure fields are becoming more similar to each other as the pressure contours of the cases with refined grids (Fig. 5 (c) and (d)) are identical.

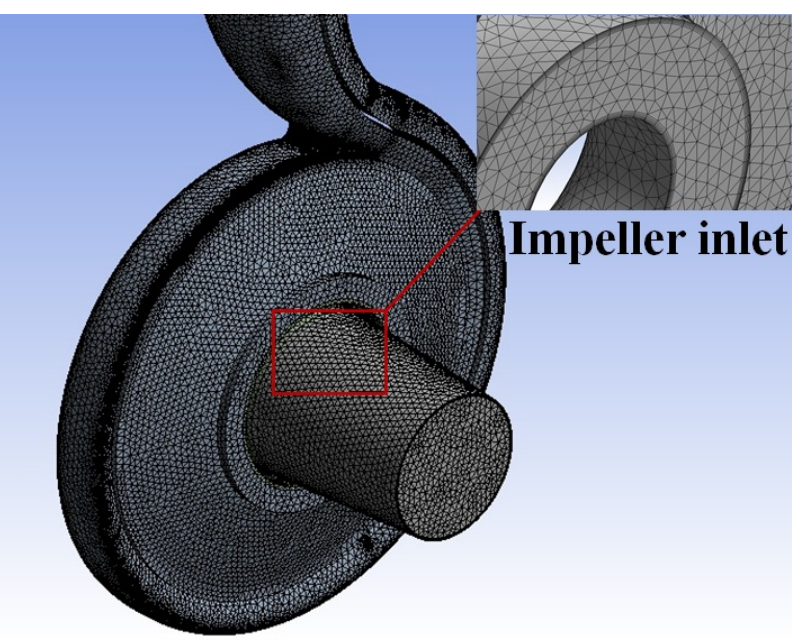

Fig. 4 Computational grid for flow domain

Table 2 Grid study

\begin{tabular}{|c|c|c|c|c|}
\hline $\begin{array}{c}\text { Grid size } \\
(\times 1000)\end{array}$ & 750 & 1091 & 1891 & 2499 \\
\hline $\begin{array}{c}\text { Torque } \\
\text { (N.m) }\end{array}$ & 1042 & 1097 & 1123.8 & 1124 \\
\hline
\end{tabular}

\section{DATA VALIDATION}

Fig. 6 compares the numerical and experimental results of the impeller with central splitter blades of $\mathrm{L}=0.5 \mathrm{Ls}$ (splitter blades have been located on the center of the two main blades). Based on data analyses the agreement among them is good and the highest deviation is 4.8 per cent. In fact, these results have been achieved in the similar operating conditions (inlet pressure and uniform flow, working fluid). As it can be seen from the Fig. 6, error bars are shown in each test point. The maximum variation of $1.1 \%$ between repeated measurements of the same quantity has been resulted. Furthermore, according to [15], calculated head, flow rate and absorbed power uncertainties are $\pm 1.7 \%, \pm 2.6 \%$ and $\pm 2.1 \%$, respectively.

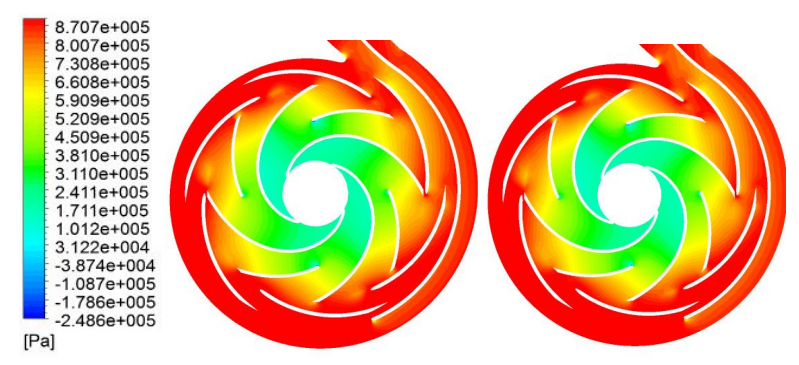

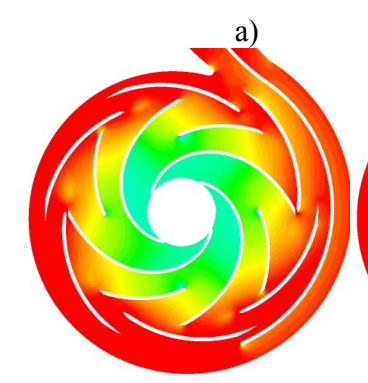

(c)

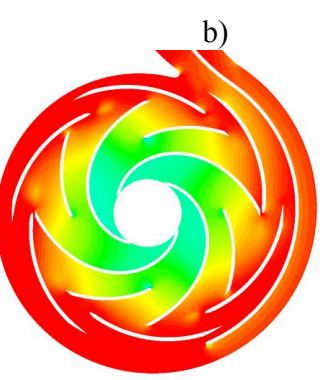

(d)
Fig. 5 Pressure contour at different grid sizes $(\times 1000)(a)$ Grid size: 750 (b) Grid size:1091 (c) Grid size: 1891 (d) Grid size:2499

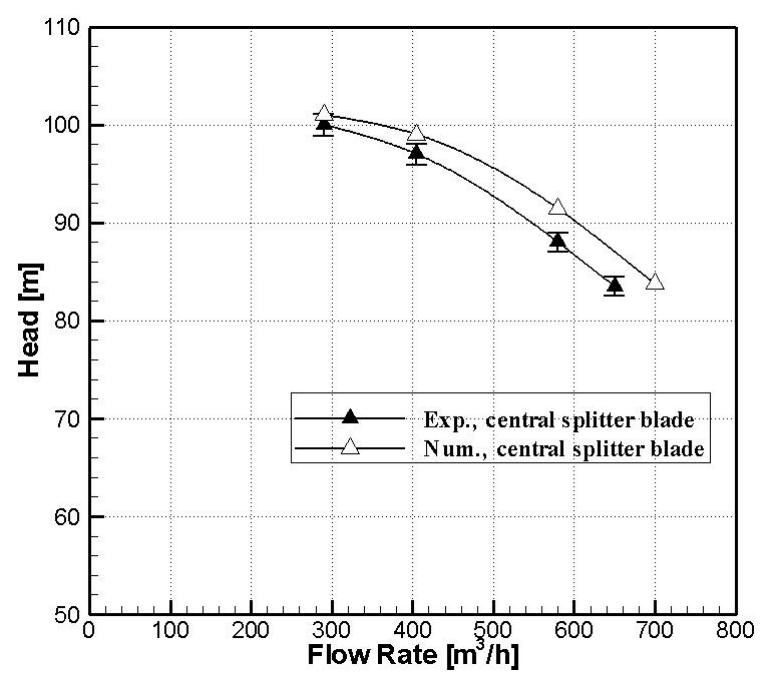

Fig. 6 Experimental and numerical results of the impeller with central splitter blades

\section{RESULTS AND DISCUSSION}

Three-dimensional computations on different configurations of splittered impellers (impeller with central splitter blades and circumferentially displaced splitter blades by $+\mathrm{Pi} / 10,+2 \mathrm{Pi} / 10,-2 \mathrm{Pi} / 10,-\mathrm{Pi} / 10(+$ is the rotating direction and $\mathrm{Pi}$ is the distance between the two main blades)) of an Over Hung type centrifugal pump equipped with the vaned diffuser have been studied. Since the aim was approaching to higher head values, based on the numerical results the impeller with optimum located splitter blades, regarding head values, was constructed and tested thoroughly.

Figure 7 demonstrates head variation of different impellers with flow rate. It is obtained that the impeller with central splitter blades has the highest head values at all flow rates. In fact, at low flow rate, head value of the impeller with central splitter blades is 7.5 percent higher than that of the impeller with shifted splitter blades by $-2 \mathrm{Pi} / 10$, which has the least head values at all flow rates. 
The reason is that the blade outlet velocity of the impeller with shifted splitter blades by $-2 \mathrm{Pi} / 10$ is the highest of all; consequently, transmission of kinetic to potential energy in this case is the lowest and resulted in the minimum head values. Additionally, as shown, head values of the impeller with shifted splitter blades by $+\mathrm{Pi} / 10$ are a bit lower than that of the impeller with central splitter blades at all flow rates. Besides, experimental and numerical head variations of the original impeller (without impeller splitter blades) with flow rate have been indicated in Fig. 7 as well.

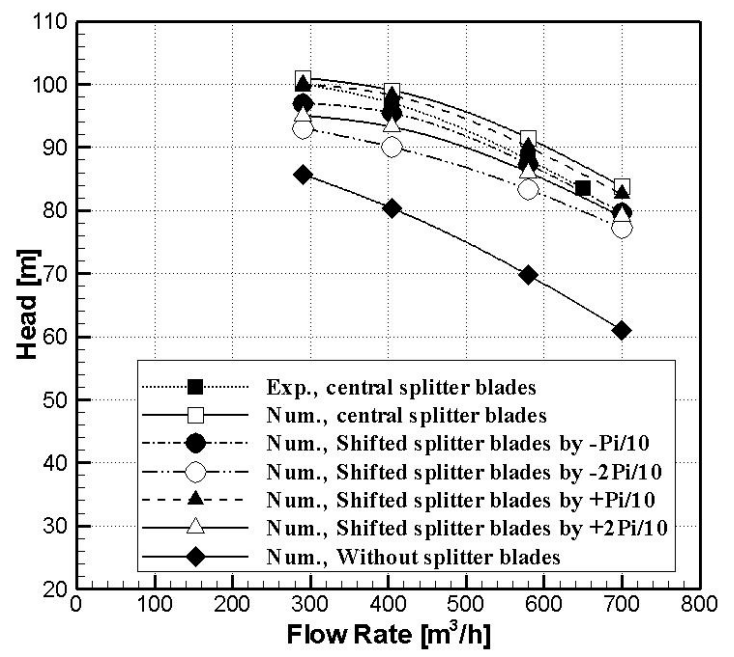

Fig. 7 Variation of head with flow rate

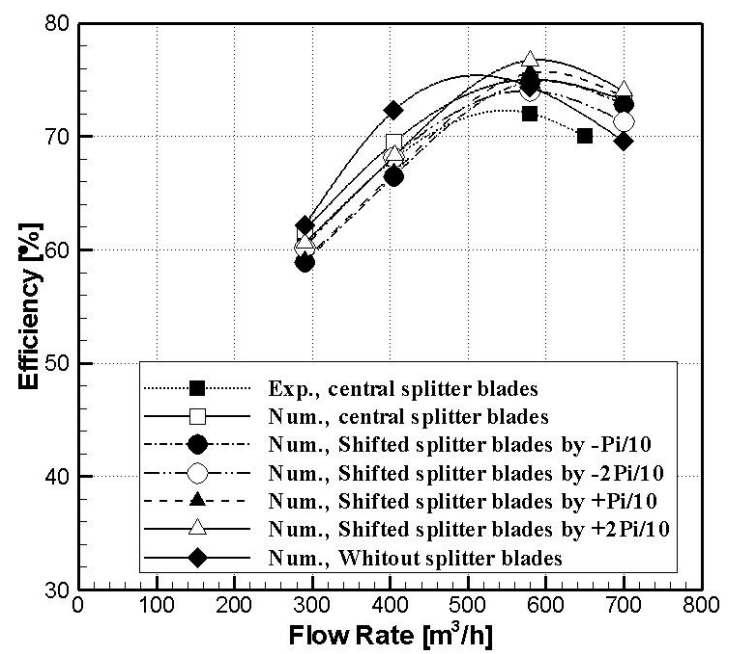

Fig. 8 Variation of overall efficiency with flow rate

Indeed, as depicted these values are lower than that of all splittered impellers and centralized splitter blades enhanced head by 26 percent at high flow rate compared to the original impeller. Efficiency variations of all investigated configurations with flow rate are presented in Fig. 8. The results revealed that overall efficiency of the impeller with shifted splitter blades by $+2 \mathrm{Pi} / 10$ is the highest at BEP, Best Efficiency Point, as it is 1.7 percent higher than that of the impeller with central splitter blades. It is also observed that in that case, efficiency of the impeller with shifted splitter blades by $+\mathrm{Pi} / 10$ increased slightly in comparison with the impeller with central splitter blades. Moreover, the impeller with shifted splitter blades by $-2 \mathrm{Pi} / 10$ has the lowest overall efficiency values at high flow rates as well. Furthermore, based on Fig. 8, BEP of the splittered impellers displaced towards the high flow rate as shifted splitter blades by $+2 \mathrm{Pi} / 10$ led to the maximum displacement of 16 percent which in this case, efficiency at BEP was 1.6 percent higher than that of the original impeller (without impeller splitter blades). In fact, more deficient impeller design is more positive changes on the centrifugal pump performance would be. As pointed out, the original impeller was existed and by surveying the effects of splitter blades numerically in different positions, the optimum case has been accomplished and manufactured and tested.

Figure 10 illustrates pressure distribution of different impellers separately at the impeller mid- height plane (Fig. 9). In Fig. 10 (a) pressure distribution of the impeller with central splitter blades is shown as it has the highest pressure gradient of all. As illustrated in Figs. 10 (b) and (c), by displacing splitter blades by $+\mathrm{Pi} / 10$ and $-\mathrm{Pi} / 10$ pressure gradient decreases and the impeller with shifted splitter blades by $-\mathrm{Pi} / 10$ has the lower pressure gradient in comparison with the impeller with shifted splitter blades by $+\mathrm{Pi} / 10$.

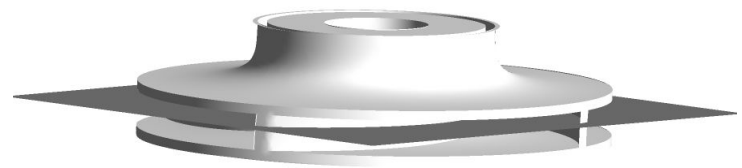

Fig. 9 Impeller mid-height plane

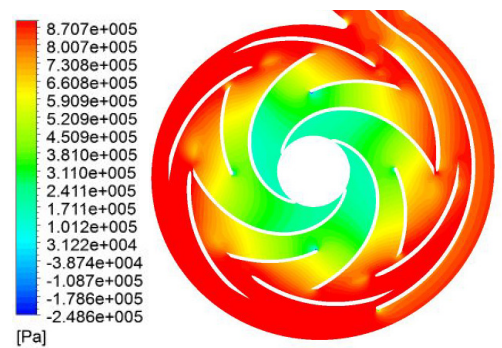

(a)

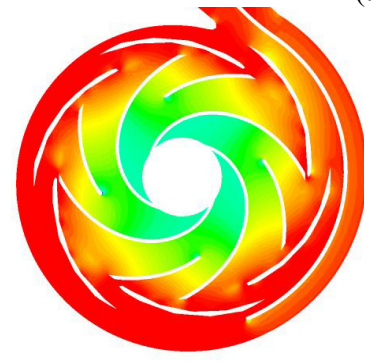

(b)

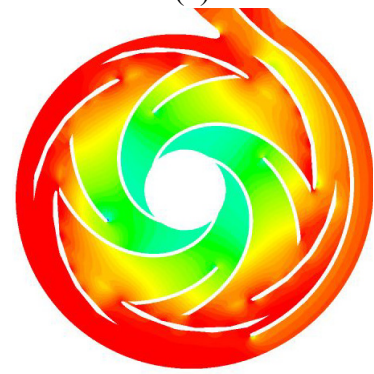

(d)

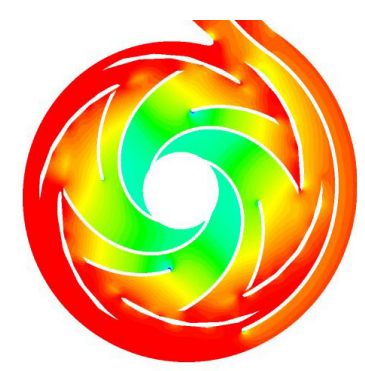

(c)

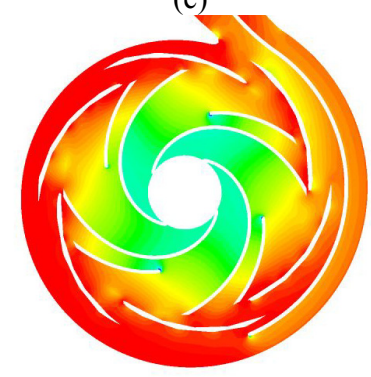

(e)
Fig. 10 Pressure distribution (a) central splitter blades (b) displaced splitter blades by $+\mathrm{Pi} / 10$ (c) displaced splitter blades by $-\mathrm{Pi} / 10$ (d) displaced splitter blades by $+2 \mathrm{Pi} / 10$ (e) displaced splitter blades by $-2 \mathrm{Pi} / 10$ 
Also, according to this figure shifted splitter blades by $-2 \mathrm{Pi} / 10$ cause more changes on pressure distribution of the impeller rather than the impeller with shifted splitter blades by $+2 \mathrm{Pi} / 10$, see Figs. 10 (d) and (e). Actually, shifted splitter blades in the opposite rotating direction cause higher non-uniform pressure distribution in impeller circumferences.

Velocity streamlines of all surveyed impellers with various splitter blades positions are demonstrated in Fig. 11. It is found that impellers with displaced splitter blades in the opposite rotating direction have higher velocity gradient in the peripheral of the impellers in comparison with the impellers with shifted splitter blades in the rotating direction. The flow fields of pressure side and suction side of the impeller blades vary among the impellers with shifted splitter blades in the different directions because of the flow distortion which considerably influences impeller performance. In fact, on the pressure side of the impellers with shifted splitter blades by $-\mathrm{Pi} / 10$ and $-2 \mathrm{Pi} / 10$ some re- circulation due to the mismatch in the blade and flow angles is resulted.

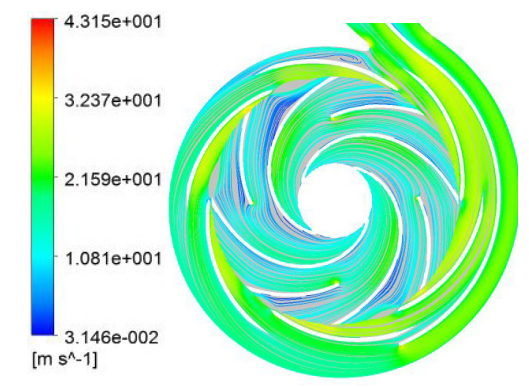

(a)

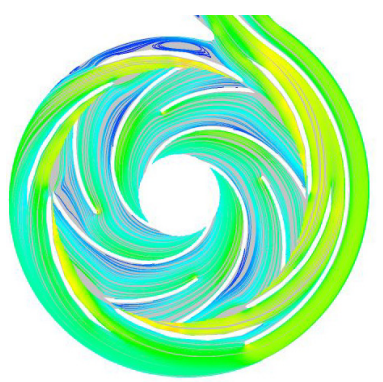

(b)

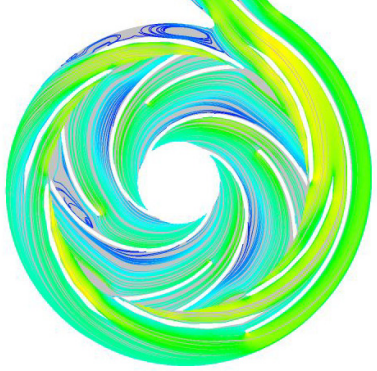

(d)

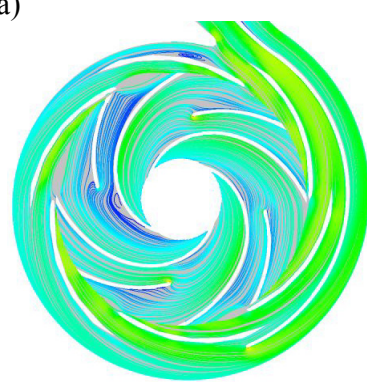

(c)

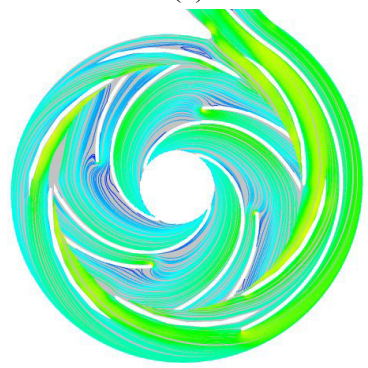

(e)
Fig. 11 Velocity streamlines (a) central splitter blades (b) displaced splitter blades by $+\mathrm{Pi} / 10$ (c) displaced splitter blades by $-\mathrm{Pi} / 10$ (d) displaced splitter blades by $+2 \mathrm{Pi} / 10$ (e) displaced splitter blades by $-2 \mathrm{Pi} / 10$

While there is no re-circulation on the pressure side of the impellers with shifted splitter blades in the rotating direction, $+\mathrm{Pi} / 10$ and $+2 \mathrm{Pi} / 10$, whereas, in these impellers particularly the impeller with shifted splitter blades by $+2 \mathrm{Pi} / 10$, some re-circulation is observed on the suction side of the impeller blades in the vicinity of splitter blades. In other words, higher uniform flow is achieved by displacing splitter blades in the rotating direction owing to the better position of the splitter blades for the bulk flow.

\section{CONCLUSIONS}

Computational and experimental investigations have been carried out to accomplish the optimum, circumferential position of the impeller splitter blades in the presence of vaned diffuser. To do so, five different configurations of splittered impellers including the impeller with central splitter blades and shifted splitter blades by $+\mathrm{Pi} / 10,+2 \mathrm{Pi} / 10,-2 \mathrm{Pi} / 10,-\mathrm{Pi} / 10 \quad(+$ is the rotating direction and $\mathrm{Pi}$ is the distance between the two main blades) have been assessed numerically and the optimum one was built and tested. Data analyses showed good compatibility between numerical and experimental results. The highest head values have been obtained by employing central splitter blades at all flow rates which is by 7.5 percent higher than that of the impeller with shifted splitter blades by $-2 \mathrm{Pi} / 10$ at low flow rate. Besides, it is found that the overall efficiency increased by 1.7 percent while utilizing the impeller equipped with shifted splitter blade by $+2 \mathrm{Pi} / 10$ at BEP, Best Efficiency Point, in comparison to the impeller with central splitter blades. Moreover, displacing splitter blades in the opposite direction of rotation caused lower efficiency values at high flow rate as the impeller with shifted splitter blades by $-2 \mathrm{Pi} / 10$ demonstrated lowest efficiency values of all.

\section{REFERENCES}

[1] Shankar VK., Umashankar S., Paramasivam S., Hanigovszki N., A comprehensive review on energy efficiency enhancement initiatives in centrifugal pumping system. Appl. Energy, Vol. 181, pp. 495-513, 2016.

[2] Wang C., Shi W., Wang X., Jiang X., Yang Y., Li W., Zhou L., Optimal design of multistage centrifugal pump based on the combined energy loss model and computational fluid dynamics. Appl. Energy, Vol. 187, pp. 10-26, 2017.

[3] Khoeini D., Riasi A., Shahmoradi A., Effects of Volute Throat Enlargement and Fluid Viscosity on the Performance of an Over Hung Centrifugal Pump, International Journal of Fluid Machinery and Systems, Vol. 10, No. 1, pp. 30-39, 2017.

[4] Skrzypacz J., Bieganowski M., The influence of micro grooves on the parameters of the centrifugal pump, International Journal of Mechanical Sciences, http://dx.doi.org/10.1016/j.ijmecsci.2017.01.039.

[5] Ivanović L. T., Erić M. D., Stojanović B. Ž., Ilić A. B., Determination of Tooth Clearances at Trochoidal Pump, FME Transactions (2011) 39, 117-126.

[6] Ye L., Yuan S., Zhang J., Yuan Y., Effects of Splitter Blades on the Unsteady Flow of a Centrifugal Pump, FEDSM2012-72155, 435-441. 
[7] Yuan S., Zhang J., Tang Y., Yuan J., Fu Y., Research on the Design Method of the Centrifugal Pump With Splitter Blades, FEDSM2009-78101, 107-120, 2009.

[8] Kergourlay G., Younsi M., Bakir F., and Rey R., Influence of Splitter Blades on the Flow Field of a Centrifugal Pump: Test-Analysis Comparison, International Journal of Rotating Machinery, Article ID 85024, 2007.

[9] Golcu M., Pancar Y., Sekmen Y., Energy saving in a deep well pump with splitter blade, Energy Conversion and Management, Vol. 47, pp. 638651, 2006.

[10] Miyamoto H., Nakashima Y., Ohba H., Effects of splitter blades on the flows and characteristics in centrifugal impellers. JSME Int. J, Ser. 2: Fluid Eng. Heat Transfer Power Combustion Thermo Physical Properties, Vol. 35, No. 20, pp. 238-46, 1992.

[11] Kui LD., Jian JL., Calculation of Complete ThreeDimensional Flow in a Centrifugal Rotor With Splitter Blades, Paper No. 88-GT-93 V001T01A041, 1988.

[12]API standard 610 (2004) Centrifugal Pumps for Petroleum, Petrochemical and Natural Gas Industries, 10th ed.

[13]ISO 9906 (1999) Rotodynamic Pumps-Hydraulic Performance Acceptance Tests-Grades 1 and 2, International Standardization Organization, Geneva.

[14]F.R. Barn Menter, Two-equation eddy-viscosity turbulence models for engineering applications," AIAA Journal, Vol. 32, No. 8, pp. 1598-1605, 1994.

[15] Moffat, R.J., Contributions to the theory of singlesample uncertainty". ASME Journal of Fluids and Engineering, Vol. 104, pp. 250-260, 1982.

\section{NOMENCLATURE}

F $\quad$ Source term

$L_{S} \quad$ Length of main blade

$P \quad$ Pressure

$P i \quad$ Distance between the two main blades

$U \quad$ Velocity

$\rho \quad$ Fluid Density

$\tau \quad$ Stress tensor scale

\section{ОПТИМАЛНИ ПОЛОЖАЈ КРАТКИХ РОТОРСКИХ ЛОПАТИЦА КОД ЦЕНТРИФУГАЛНЕ ПУМПЕ СА ДИФУЗОРСКИМ ЛОПАТИЦАМА}

\section{Д. Коеини, М.Р. Таваколи}

Рад се бави нумеричким и експерименталним истраживањем оптималног ободног положаја кратких роторских лопатица центрифугалне пумпе са дифузорским лопатицама. У ствари, анализом је обухваћено пет различитих ободних положаја кратких роторских лопатица, у централном и помереном положају за $+\mathrm{Pi} / 10,+2 \mathrm{Pi} / 10,-2 \mathrm{Pi} / 10$, $\mathrm{Pi} / 10$ (+ је правац ротације а Pi је растојање између две главне лопатице).

Експериментални и нумерички резултати указују на постојање слагања и максималне девијације главе од $4,8 \%$. Анализа података показује да је укупна искоришћеност пумпе повећана за 1,7\% најефикасније тачке (BEP), коришћењем ротора са кратким лопатицама за $+2 \mathrm{Pi} / 10$ у поређењу са ротором са централно постављеним кратким лопатицама. Штавише, утврђено је да ротор са централним положајем кратких лопатица има највеће вредности главе при свим протоцима пошто је већи за 7,5\% него код кратких лопатица у помереном положају за -2Pi/10. 